\title{
Sistem Navigasi Indoor Menggunakan Bi- Directional Dijkstra Search Berbasis Integrasi dengan Smartphone untuk Studi Kasus pada Gedung Bertingkat
}

\author{
Mohammad Ardhiansyah Metana Putra, R. V. Hari Ginardi, dan Abdul Munif \\ Jurusan Teknik Informatika, Fakultas Teknologi Informasi, Institut Teknologi Sepuluh Nopember \\ (ITS) \\ J1. Arief Rahman Hakim, Surabaya 60111 Indonesia \\ e-mail: hari@its.ac.id, munif@if.its.ac.id, metana.p12@mhs.if.its.ac.id
}

\begin{abstract}
Abstrak-Saat ini kebutuhan masyarakat akan informasi lokasi sangat tinggi, terutama dengan memanfaatkan teknologi teknologi Global Positioning System (GPS). GPS merupakan salah satu teknologi yang bisa digunakan untuk melakukan navigasi diluar ruangan, namun ketika berada di dalam ruangan atau bangunan sistem ini memiliki akurasi yang rendah, apalagi untuk ruangan/gedung yang besar. Oleh karena itu, sebuah sistem yang lebih akurat untuk memberikan solusi bagi pendeteksian lokasi di dalam ruangan atau gedung yang memiliki lebih dari satu level lantai dikembangkan dengan konsep $3 D$ Indoor Navigation System. Sistem yang dibangun dapat menunjukan posisi pengguna dengan menggunakan Indoor Localization System dengan memanfaatkan Received Signal Strength (RSS) dan rute navigasi dalam tampilan peta 3D menggunakan Bi-Directional Algorithm untuk melakukan pencarian rute terdekat antar dua tempat. Untuk mengembangkan tampilan peta 3D digunakan Unity3D. Hasil pengujian sistem menunjukan bahwa sistem ini dapat menampilkan lokasi pengguna dan rute perjalanan pada peta 3D serta pengguna bisa melakukan navigasi pada peta tersebut. Dapat ditarik kesimpulan bahwa sistem ini dapat lebih membantu pengguna dalam menemukan tempat yang ingin dituju pada studi kasus gedung Teknik Informatika ITS.
\end{abstract}

Kata Kunci-Bi-Directional Dijkstra, Indoor Localization, Location Based Service, Navigasi.

\section{PENDAHULUAN}

$\mathrm{S}$ AAT ini ada banyak bangunan tinggi dan besar yang terdiri dari berbagai lantai dan ruangan di dalamnya. Pada umumnya gedung-gedung bertingkat menyediakan sistem layanan informasi yang dapat dimanfaatkan oleh pengunjung untuk mendapatkan informasi dan lokasi tujuan. Sistem layanan informasi yang diberikan biasanya berbentuk pos-pos layanan informasi yang dijaga oleh petugas. Pengunjung yang ingin mendapatkan informasi harus bertanya kepada petugas. Namun pada kenyataannya terdapat beberapa permasalahan seperti dibutuhkan waktu yang relatif lama dalam mencari informasi yang dibutuhkan, dan juga informasi yang diberikan petugas belum tentu akurat dan kurang detail. Sehingga membuat pengunjung kesulitan dalam mencari informasi yang dibutuhkan.

Teknologi yang biasa digunakan untuk mendapatkan informasi lokasi dan rute perjalanan adalah Global Positioning
System (GPS). GPS mempunyai manfaat yang cukup besar, namun sistem ini memiliki akurasi yang rendah saat berada di suatu ruangan atau bangunan. GPS hanya dapat menunjukan daerah atau nama jalan pada lokasi pengguna, akan tetapi sistem ini tidak dapat menunjukan lokasi ruangan pada suatu bangunan dimana pengguna berada dan GPS tidak bisa memberikan rute perjalanan kepada pengguna. Hal ini terjadi karena ketidakmampuan gelombang radio yang dikirimkan oleh satelit untuk menembus benda padat dan tebal seperti tembok ruangan, gedung bertingkat dan lain sebagainya [1].

Seiring dengan kebutuhan informasi yang cepat dalam mendapatkan posisi dan rute perjalanan maka dibutuhkan kekuatan sinyal $\mathrm{Wi}-\mathrm{Fi}$ dan algoritma pencarian rute terpendek. Setiap lokasi yang ada akan memiliki beragam kekuatan sinyal dari $W i-F i$ yang berbeda, sehingga setiap lokasi akan unik karena kekuatan sinyal $W i-F i$ akan berbeda. Algortima pencarian rute terpendek menggunakan vertex, hal ini digunakan karena algoritma bekerja menggunakan graph untuk penentuan rute lintasan terpendek. Untuk mendapatkan navigasi yang akurat, terdapat dua tahap. Tahap pertama, tahap pembuatan peta, pada tahap ini peta dibuat dengan menempatkan vertex di tempat-tempat tertentu seperti persimpangan dan di depan ruangan. Tahap kedua, tahap pencarian rute, mencari jarak terpendek dengan vertex terdekat yang telah dibuat di peta dan meneruskan rute dengan melanjutkan ke vertex berikutnya sampai ke tujuan.

Pada Tugas Akhir ini, 3D Indoor Navigation akan menggunakan Indoor Localization untuk mendapatkan posisi dan Bi-Directional Dijkstra Search untuk mencari rute terpendek di Gedung Teknik Informatika ITS.

\section{TINJAUAN PUSTAKA}

\section{A. Location Based Service (LBS)}

Location Based Services (LBS) atau layanan berbasis lokasi adalah layanan informasi yang dapat diakses melalui mobile device dengan menggunakan mobile network, yang dilengkapi kemampuan untuk memanfaatkan lokasi dari mobile device tersebut. Layanan berbasis lokasi dapat digambarkan sebagai suatu layanan yang berada pada pertemuan tiga teknologi yaitu: Geographic Information System, Internet Service, dan Mobile 
Device [2]. Ada beberapa teknologi yang digunakan LBS untuk mendapatkan lokasi geografis dari sebuah perangkat mobile, di antaranya Global Positioning System, Indoor Positioning System, dan Indoor Localization. Salah satu contoh dari aplikasi yang menggunakan konsep LBS adalah aplikasi maps.

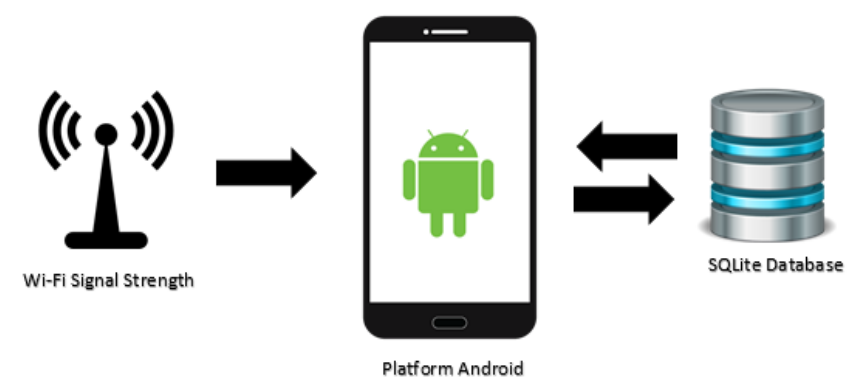

Gambar 1. Arsitektur Sistem

B. Indoor Localization Menggunakan Sinyal Wi-Fi dan Clustering Filtered K-Nearest Neighbors

Sistem indoor localization yang memiliki kemampuan untuk mendeteksi lokasi pengguna di dalam ruangan dengan menggunakan data kekuatan sinyal Wi-Fi yang ditangkap oleh smartphone pada ruangan tersebut. Hasil yang didapatkan adalah informasi lokasi pengguna seperti: nama ruangan atau area lokasi keberadaan pengguna serta tingkat lantai dari lokasi tersebut.

Sistem ini telah dikembangkan pada studi kasus pada Gedung Teknik Informatika ITS. Sistem memberikan performa yang baik dengan persentase rata-rata akurasi pendeteksian lokasi sebesar 93,21\% untuk seluruh test area pada setiap lokasi uji coba [3].

\section{Unity3D Game Engine}

Unity3D adalah sebuah game engine yang dikembangkan oleh Unity Technologies yang juga merupakan tool data yang digunakan tidak hanya untuk membuat game tetapi juga konten, animasi 3D waktu nyata, dll. Unity dapat berjalan pada Windows dan Macintosh OS X dan digunakan untuk pengembangan pada platform yang bermacam-macam termasuk Windows, Mac, Wii, iPhone, Android, dan lain-lain. Unity juga dapat digunakan untuk membuat game 3D berbasis web dengan menggunakan plug-in Unity Web Player [4].

\section{SQLite}

SQLite adalah sebuah open source database sangat terkenal pada perangkat kecil seperti Android karena cukup stabil. Pada platform Android, SQLite dijadikan satu di dalam Android runtime, sehingga setiap aplikasi Android dapat membuat basis data SQLite. SQLite menggunakan antarmuka SQL, sehingga cukup mudah untuk digunakan [5].

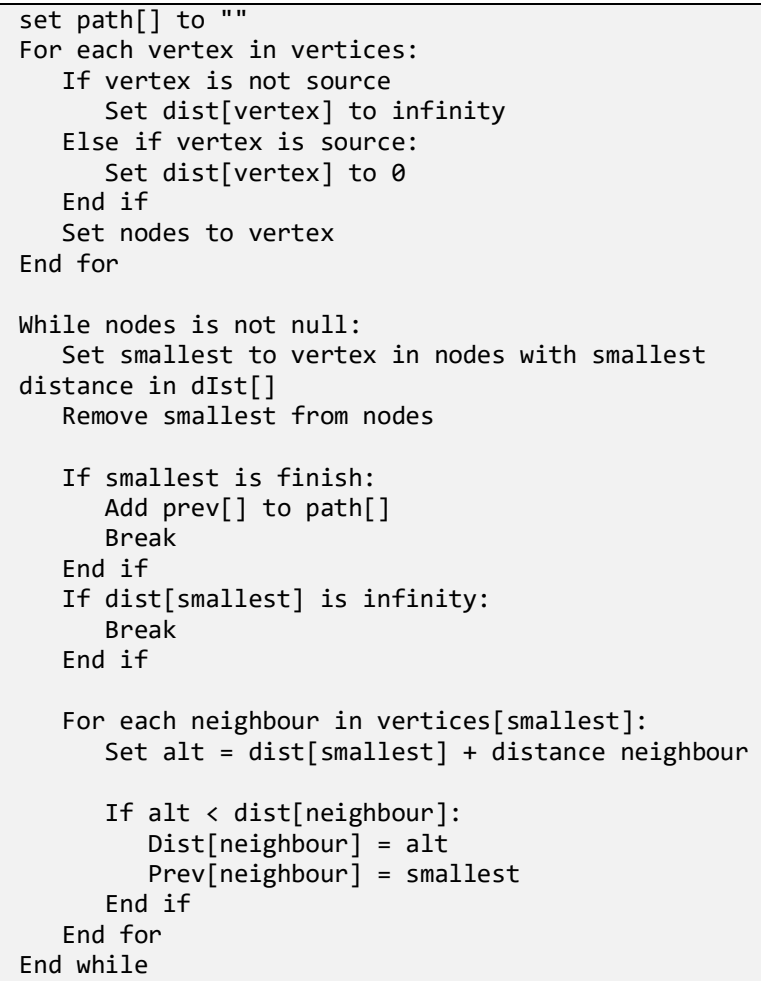

Kode Sumber 1. Pseudocode algoritma Dijkstra

\section{E. Algoritma Dijkstra}

Algoritma Dijkstra merupakan algoritma untuk menemukan jalur terpendek antar vertex dalam sebuah graph. Algoritma ini dinamakan sesuai dengan penemunya Edsger W. Dijkstra. Edsger Wybe Dijkstra merupakan seorang ilmuwan komputer berkebangsaan Belanda. Algoritma ini ditemukan dipublikasikan pada tahun 1959 [6]. Dalam pengaplikasian algoritma Dijkstra dalam suatu permasalahan, diperlukan beberapa syarat berikut:

1. Graph yang digunakan dapat berupa graph yang memiliki arah maupun yang tidak memiliki arah.

2. Semua edge pada graph harus memiliki weight nonnegative.

3. Graph harus terhubung.

Pseudocode algoritma Dijkstra ditunjukan pada Kode Sumber 1.

\section{F. Algoritma Bi-Directional Dijkstra}

Langkah awal untuk menggunakan algoritma Bi-Directional Dijkstra adalah menentukan vertex awal dan vertex akhir. Setelah itu di vertex titik tersebut akan dijalankan secara bersamaan menggunakan algoritma Dijkstra. Dengan cara ini rute terpendek dapat diperoleh dari data yang telah dikumpulkan. Teknik ini memungkinkan untuk mempercepat pencarian rute dibandingkan algoritma Dijkstra biasa [7].

Pseudocode algoritma Bi-Directional Dijkstra ditunujukan pada Kode Sumber 2.

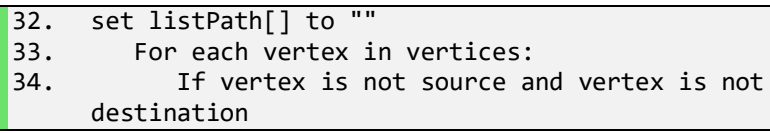




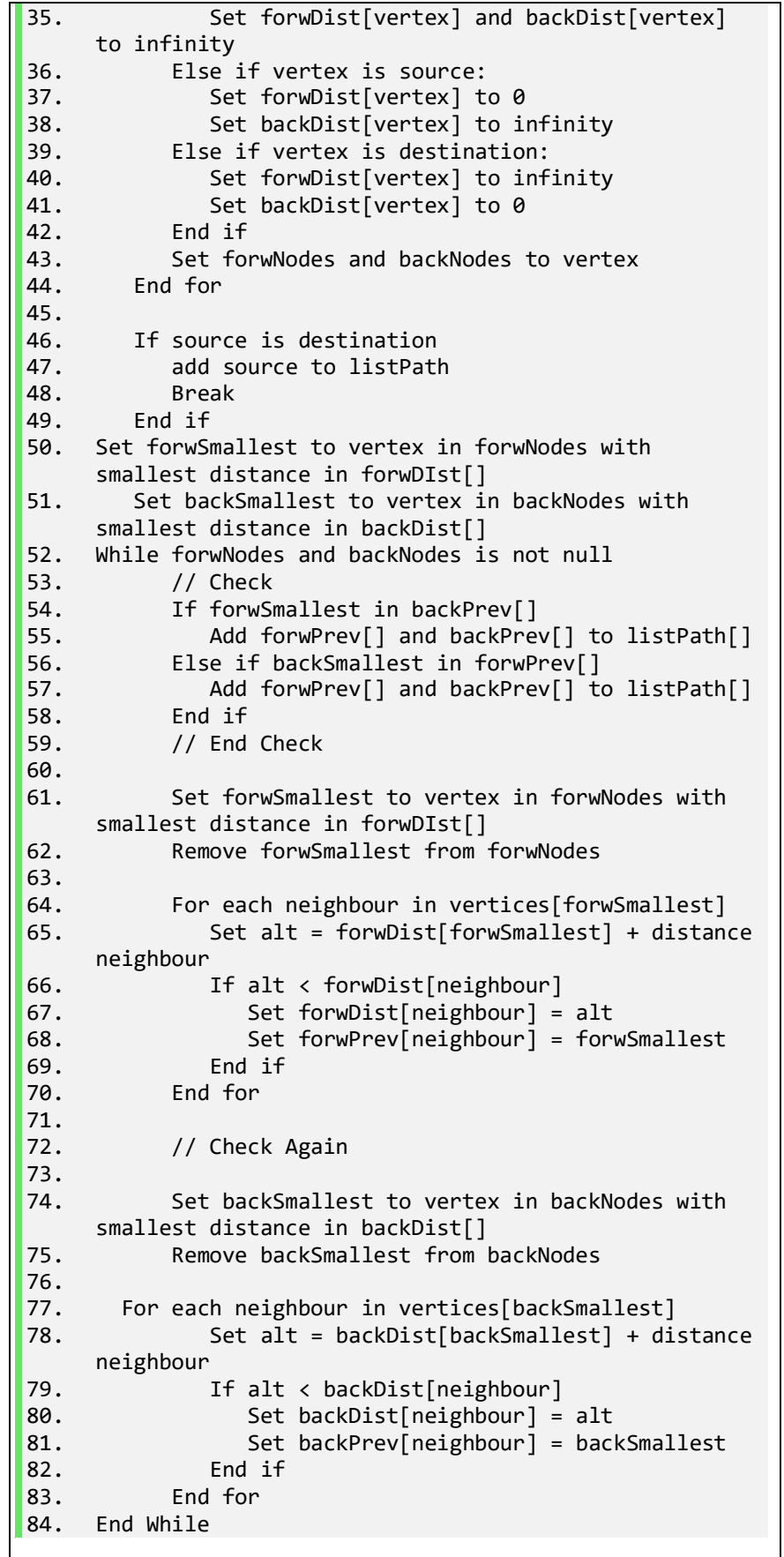

Kode Sumber 2. Pseudocode algoritma Bi-Directional Dijkstra

\section{ANALISIS DAN PERANCANGAN}

\section{A. Analisis Sistem}

Aplikasi yang akan dibangun merupakan aplikasi berbasis perangkat bergerak Android. Aplikasi ini memiliki kemampuan untuk menentukan posisi, rute terbaik, dan arah perjalan untuk mencapai lokasi tujuan pengguna. Semua informasi tersebut akan disajikan pada layar smartphone pengguna.

Kebutuhan utama dalam aplikasi ini antara lain:

1. pengguna dapat mengetahui posisi keberadaannya,

2. pengguna dapat melakukan navigasi

\section{B. Perancangan Sistem}

Arsitektur sistem pada aplikasi indoor navigation ini ditunjukkan pada Gambar 1. Berdasarkan gambar tersebut, informasi lokasi pengguna dapat diketahui dengan mendeteksi data sinyal Wi-Fi yang ditangkap pada saat itu kemudian data tersebut diolah untuk mendapatkan informasi lokasi pengguna yang kemudian digunakan sebagai titik awal pada pencarian rute menuju tujuan.

\section{Perancangan Proses dan Alur Sistem}

Proses yang dibangun pada sistem ini meliputi proses prediksi lokasi pengguna, proses pencarian rute terpendek, serta proses menampilkan rute pada peta. Pada proses prediksi lokasi pengguna, data-data mengenai sinyal $\mathrm{Wi}-\mathrm{Fi}$ disekitar pengguna akan diambil dan diolah dengan memanfaatkan sistem indoor localization. Setelah sistem indoor localization mendapatkan lokasi pengguna maka akan dilakukan proses pencarian rute terpendek dengan menggunakan algoritma Bi-Directional Dijkstra data prediksi lokasi pengguna akan digunakan sebagai data source dan data destination akan dimasukkan manual oleh pengguna. Setelah rute pencarian didapatkan maka rute akan ditampilkan pada peta 3D.

\section{IMPLEMENTASI SISTEM}

Pada bagian implementasi sistem, dibangun aplikasi navigation indoor berbasis perangkat bergerak Android. Aplikasi ini dibangun dengan bahasa pemrograman C\# dengan menggunakan Unity3D Game Engine sebagai IDE. Aplikasi ini digunakan untuk menjalankan berbagai fungsionalitas sistem yang ditampilkan dalam antarmuka halaman utama.

Ketika membuka aplikasi untuk pertama kali, sistem akan mengaktifkan koneksi Wi-Fi jika sebelumnya belum diaktifkan. Koneksi $W i-F i$ digunakan untuk mengambil data-data sinyal Wi-Fi di sekitar pengguna. Antarmuka halaman utama adalah antarmuka yang berisi semua fitur aplikasi yaitu fitur untuk melakukan prediksi lokasi pengguna saat ini yang ditunjukan dengan tombol berwarna oranye, dan informasi lokasi akan ditunjukan dengan perubahan posisi sudut pandang dan informasi ruangan ditunjukan pada kolom bagian atas, fitur selanjutnya adalah fitur pencarian dan menampilan rute yang ditunjukan dengan dua kotak tulisan yang bisa diisi nama ruangan oleh pengguna sebagai awal dan tujuan navigasi serta tombol panah digunakan untuk mencari dan menampilkan rute pencarian pada peta 3D. Antarmuka halaman utama ditunjukan oleh Gambar 2.

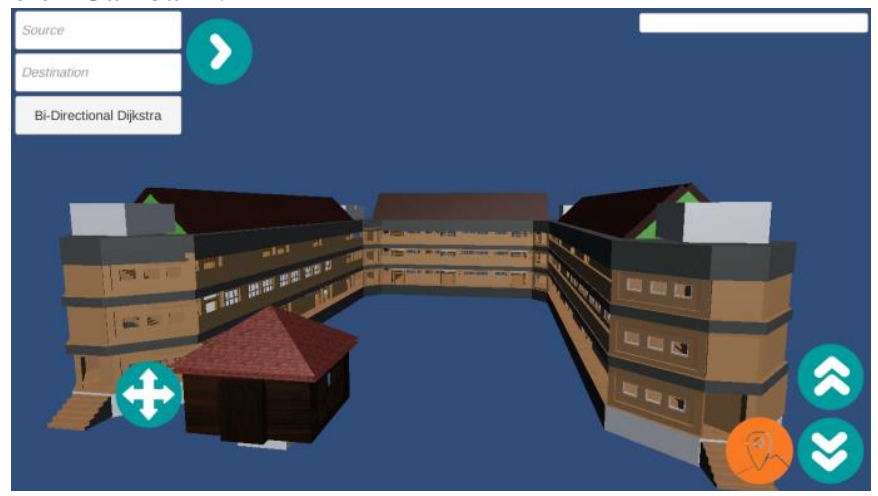

Gambar 2. Antarmuka halaman utama 


\section{PENGUJIAN TERHADAP PENGGUNA}

Pengujian terhadap sistem yang telah selesai dibangun meliputi pengujian fungsionalitas pengujian kinerja serta analisa algoritma. Pengujian fungsionalitas dilakukan dengan metode blackbox. Pengujian fungsionalitas dikatakan berhasil ketika kondisi akhir sesuai dengan kondisi yang diharapkan. Pengujian fungsionalitas yang dilakukan ada 3 macam yaitu:

1. Menampilkan posisi pengguna, dengan posisi awal dalam gedung belum diketahui kemudian pengguna menekan tombol GetPosition pada aplikasi untuk mengetahui lokasi dan mendapatkan informasi pada peta 3D.

2. Menampilkan rute navigasi, pada kondisi sebelumnya tidak ada rute navigasi yang ditampilkan sehingga pengguna perlu memasukan data source dan destination kemudian menekan tombol GetRoute untuk menampilkan rute navigasi pada peta $3 \mathrm{D}$.

3. Melakukan proses navigasi, dengan kondisi awal pengguna belum bergerak. untuk melakukan proses navigasi ada 3 macam skenario yang dapat dilakukan, menekan dan menggerakan tombol Rotate untuk merubah posisi hadap pengguna, menekan tombol Forward untuk menggerakan penguna maju ke depan, dan menekan tombol Backward untuk menggerakan pengguna mundur ke belakang.

Pengujian kinerja dilakukan langsung ke beberapa smartphone dengan cara menggunakan aplikasi untuk melakukan navigasi pada keadaan sebenarnya. Pengujian ini bertujuan untuk mengukur kinerja sistem pada lebih dari satu smartphone dengan parameter kecepatan menampilkan peta 3D dan rute perjalanan. Hasil yang didapatkan menunjukan bahwa aplikasi bisa berjalan dengan lancar pada semua smartphone.

Analisa algoritma dilakukan dengan membandingkan algoritma Bi-Directional Dijkstra sebagai algoritma utama dan algoritma Dijkstra sebagai algoritma pembanding. Pada pengujian ini digunakan titik awal dan titik akhir yang sama namun running time yang diperoleh berbeda. Iterasi yang dilakukan kedua algoritma tersebut membutuhkan waktu $\mathrm{O}(\log n)$, running time yang didapatkan Bi-Directional Dijkstra sebesar $\mathrm{O}(\sqrt{n} \log n)$, sedangkan Dijkstra didapatkan running time selama $\mathrm{O}(n \log n)$. Dengan demikian algoritma $B i$ Directional Dijkstra memiliki running time lebih cepat dibandingkan algoritma Dijkstra. Hal ini karena algoritma Dijkstra mencari semua kemungkinan rute dengan cara mengecek semua vertex pada graph dari source menuju destination, sedangkan algoritma Bi-Directional Dijkstra mencari rute dengan menjalankan algoritma Dijkstra dari source menuju destination dan dari destination menuju source dan akan berhenti ketika kedua path bertemu dan digabungkan menjadi satu path.

Tabel 1.

Hasil pengujian fungsionalitas

\begin{tabular}{llc}
\hline \hline No & \multicolumn{1}{c}{ Nama Pengujian } & Hasil Pengujian \\
\hline 1 & Menampilkan posisi pengguna & Berhasil \\
2 & Menampilkan rute navigasi & Berhasil \\
3 & Melakukan proses navigasi & Berhasil \\
\hline \hline
\end{tabular}

Tabel 2

Hasil pengujian kinerja

\begin{tabular}{cccc}
\hline \hline \multirow{2}{*}{ No } & \multirow{2}{*}{ Jenis Smartphone } & \multicolumn{2}{c}{ Kecepatan Menampilkan } \\
& & Peta 3D & Rute \\
\hline 1 & Oppo R7 Lite & $6 \mathrm{~ms}$ & $3 \mathrm{~ms}$ \\
2 & Xiaomi Redmi Note 2 & $6 \mathrm{~ms}$ & $3 \mathrm{~ms}$ \\
3 & Infinix Hot 2 & $7 \mathrm{~ms}$ & $5 \mathrm{~ms}$ \\
\hline
\end{tabular}

Tabel 3.

Hasil analisa algoritma

\begin{tabular}{lll}
\hline \hline No & \multicolumn{1}{c}{ Nama Algoritma } & \multicolumn{1}{c}{ Runtime } \\
\hline 1 & Dijkstra & $\mathrm{O}(n \log n)$ \\
2 & Bi-Directional Dijkstra & $\mathrm{O}(\sqrt{n} \log n)$ \\
\hline
\end{tabular}

Hasil pengujian fungsionalitas ditunjukan oleh Tabel 1, hasil pengujian kinerja ditunjukan oleh Tabel 2 dan hasil analisa algoritma ditunjukan oleh Tabel 3.

\section{KESIMPULAN/RINGKASAN}

Selama proses perancangan, implementasi, dan pengujian dapat diambil kesimpulan sebagai berikut:

1. Proses memanfaatkan sistem Indoor Localization menggunakan sinyal $\mathrm{Wi}-\mathrm{Fi}$ sebagai penentu posisi pengguna pada sistem $3 D$ Indoor Navigation dilakukan dengan memanfaatkan fungsi Clustering Filtered $k$ Nearest Neighbors pada sistem Indoor Localization dan menerapkannya pada sistem $3 D$ Indoor Navigation.

2. Penerapan algoritma Bi-Directional Dijkstra dalam mencari rute terpendek dilakukan dengan menggunakan graph yang terdiri dari vertex dan edge. Vertex menunjukan lokasi ruangan dan persimpangan pada Gedung Teknik Informatika dan edges adalah jarak antara dua lokasi yang bersebelahan.

3. Pengguna dapat mengetahui rute perjalanan dengan memasukan data asal pada kolom source dan data tujuan pada kolom destination. Informasi rute perjalanan ditunjukan dengan garis berwarna ungu pada halaman utama.

4. Algoritma Bi-Directional Dijkstra terbukti lebih cepat daripada algoritma Dijkstra. Hal ini ditunjukan dengan perbandingan kompleksitas yaitu untuk algoritma $B i$ Directional Dijkstra $\mathrm{O}(\sqrt{n} \log n)$ dan untuk algoritma Dijkstra $\mathrm{O}(n \log n)$.

\section{UCAPAN TERIMA KASIH}

Penulis M.A.M.P. mengucapkan terima kasih kepada Jurusan Teknik Informatika Institut Teknologi Sepuluh Nopember atas segala bantuan dan bimbingannya dalam menempuh ilmu dan meraih gelar Sarjana dalam tahun 20122016.

\section{DAFTAR PUSTAKA}

[1] H. Fredrick, "Why Doesn't GPS Work Inside a Building?," OpposingViews.com, [Online]. Available: http://science.opposing views.com/doesnt-gps-work-inside-building18659.html. [Accessed 25 May 2016].

[2] S. Steiniger, M. Neun and A. Edwardes, "Foundations of Location Based Services," Lecture Notes on LBS, 2006. 
[3] M. F. Ghanianto, Implementasi Indoor Localization Menggunakan Sinyal Wifidan Clustering Filtered K-Nearest Neighbors untuk Pelacakan Keberadaan Seseorang dan Evaluasi Akurasi Pelacakan di Kampus Teknik Informatika ITS, Surabaya, 2015.

[4] Unity Technologies, "Unity Game Engine," 2016. [Online]. Available: https://unity3d.com/. [Accessed 13 May 2016].

[5] "About SQLite," [Online]. Available: https://www.sqlite.org/about.html. [Accessed 11 June 2016].

[6] M. Sniedovich, "Dijkstra's Algorithm," The University of Melbourne, 27 February $2005 . \quad$ [Online]. Available: http://www.ms.unimelb.edu.au/ moshe@unimelb/620261/Dijkstra/Dijkstra.html. [Accessed 7 Juny 2016].

[7] M. Dramski, "Bi-Directional search in route planning in navigation," Scientific-Journals, pp. 57-62, 2014. 